\title{
TOURISM AND ITS INFLUENCE UPON MACRO-ENVIRONMENT IN ROMANIA
}

\author{
Scorțe Carmen ${ }^{1}$
}

ABSTRACT: Tourism is a complex social and economic phenomenon specific to modern civilization, an essential activity in the life of nations, being strongly influenced by the freedom of travel and the evolution of society. Addressing to large shares of the population and meeting the human need for travelling and knowledge, recreation and healing, tourism is characterized by a high momentum both nationally and globally, resulting in a vast human and material potential, with important implications upon the evolution of the entire society.

Hospitality and tourism industry are nowadays considered to stand for the largest business in the world, being the main industry in point of their contribution to the gross world product, labor committed as well as the most important capital investor.

The objective of our article is to analyze the evolution of several indicators of tourist traffic and their influence on the macro-environment in Romania. As far as the research methodology is concerned, the article is based on a positivist quantitative approach, being in the same time a longitudinal one, as we present the evolution of various indicators measuring the degree of impact the hospitality industry has on the national economy.

The main information sources for this research are published on the websites of various authorized bodies (NIS, NBR, WTO), using exploratory method for analyzing the evolution of the phenomenon in time, but I also considered the interpretive method when disclosing the analysis results.

Key words: Tourism, macro-environment, tourist traffic indicators

JEL Codes M21, E 29

\section{Introduction}

Tourism is a strategic economic activity in Romania, its importance in the national economy being likely to increase in the coming years. Tourism covers a wide range of products and destinations and involves many stakeholders from both public and private sector alike, and has accommodation and restoration as main activity domains. Tourism has great potential in contributing to the achievement of many of Romania's major objectives such as sustainable development, economic growth, employment and economic and social cohesion as well.

Firstly, tourism and hospitality refer to all the activities by means of which man spends his free time, and secondly, to the goods and services industry created to meet the desires, preferences and motivations required by tourists at the destination.

The Romanian Explanatory Dictionary defines tourism as the recreational or sporting activity, consisting of crossing on foot or by various means of transport of a region considered as picturesque and interesting from a particular point of view (DEX, 1998).

A famous work "The Shorter Oxford English, Dictionary" (1950) defines tourism as “... theory and practice of field trips, the trip being for pleasure" and the tourist as "... the one who makes one or more tours, especially the one who does this for recreation; the one who travels for

\footnotetext{
${ }^{1}$ University of Oradea, Faculty of Economics, Romania, email: carmen.scorte@yahoo.com
} 
pleasure or for cultural purposes, visiting different interesting places for their objectives, landscape or others alike."

According to Dictionnaire Touristique International (1969) tourism is a set of measures implemented so as to organize and perform some leisure trips, or for other purposes, made either through specialized companies, or on their own for a limited period of time. The most popular sense of the term tourism is the one that involves overnight outing in a location for at least one night and tends to be synonymous with vacations or holidays (Medlik, 2003). However, according to World Tourism Organization (UNWTO), tourism involves "activities of persons who travel and stay in places outside their usual environment ... for recreation, business and other purposes" (Medlik, 2003). A suggested clarification refers to tourism that "denotes a temporary short term movement of people to destinations outside their normal environment and their activities in this broad concept, technical definitions are formulated so as to serve certain purposes, to include or exclude certain trips and visits, especially by reference to criteria such as scope, time and distance."(Medlik, 2003).

Many define tourism defined not by what it is, but by what it is not. It is neither home, nor working place. Thus we get definitions like "non-business tourism" - that refers to a person performing one or more recreational activities during his spare time, in a temporary location away from the place of residence and in a special location where such activities are regularly conducted or "business tourism" aimed at a specific person who undertakes his work in a temporary location remote from his place of residence or regular employment. (Franklin, 2003). We could say that, by these definitions, the author reduces tourism to leisure activities happening after travel activities have been performed.

Demand-based definitions emphasize the acception of tourism as human activity (Smith, 1992) like the one used in the Final Report of the U.S. National Tourism Policy Study. That report suggests that tourism is "the act or activities that people undertake when traveling from one place to another outside their communities for any purpose other than commuting to and from work" (Smith, 1992). Although many authors consider "tourism" and "trip" as synonymous, the tendency is to consider "tourism" taking into account the above definition, and "trip" as the human movement by means of any vehicle for journey sake. Smith tries to combine the supply and demand, defining tourism as: "(1) Activities of travelling and the set of actions undertaken by people during journeys to places far from home. 2) The aggregate of all businesses that directly provide goods or services to facilitate business, leisure or spending spare time away from home. (3) A combination of these two phenomena. (Smith, 1992).

Based on its role and functions tourism results from the combined effect of several branches. Some of them - construction, car engineering industry, electronics and electro-technical industry, wood and textile industry, agriculture and food industry - find themselves as supplying branches, and their supplies are incorporated either in the material basis of tourism or in the output of public catering providers. The large number of branches which contribute to the making of the travel benefits indicates that the "tourism product" can be superior only if all these branches contribute to its making with high quality items.

The importance of tourism in a country's economy can be defined by: its contribution to national income; a higher recovery of resources in the territory; economic development of areas devoid of soil or subsoil riches; stabilization of labor force; insurance of normal circulation of money; energizing element for the global economic system; means of diversifying economic structures; training and education factor; regulator of the balance of payments; important calling for each nation.

\section{The system of indicators for international tourism}

International tourism indicators provide and quantify information necessary for the tourist policy actions, allowing subsequent measurement of the effects of those actions. These are 
calculated using a series of basic statistical information, able to provide comparable, reliable and consistent data.

Like any activity that adds value, and whose results are to be found in the GDP and is also added to domestic and international flows, tourism is analyzed and monitored in its development by means of a system of specific indicators. Reference studies show that the main research tools for tourism are direct and complete observations as well as partial observations of the phenomenon. They are applied to key tourist activity, namely at the border, in the accommodation places when financial transactions are fulfilled. International tourism, defined as all phenomena and relationships arising from the movement and stay of persons visiting a country, other than their country of residence are, in the opinion of most experts, the most dynamic component of the tourist circulation (Gabriela Stănciulescu et al, 1998). In recent years, international tourism has experienced the greatest increase due to people's desire to visit other countries, to know other cultures and customs, and also to the technical progress in transport, the breakthrough that allows faster and more comfortable travelling for increasingly longer distances. (Alison Nistoreanu 2005).

The drafting of a relatively uniform statistical methodology comparable to the international one, is a problem specialists have been dealing with for many years. As tourism is a phenomenon difficult to quantify, this activity has not received a proper statistical information system for a long period of time. This is perhaps due to low initial share of tourism in GDP and especially in the invisible international trade. (Hapenciuc Cristian Valentin, 2004).

Tourism indicators capture and reproduce in a synthetic and mathematic expression, the information on various aspects of tourism, useful information for measuring the phenomenon and its effects when anticipating evolution trends and fundamenting the development policy in the field. The making of indicators and their diversity depend on the availability of primary sources of data collection, of appropriate work methods and techniques (Rodica Minciu, 2004).

The system of indicators presented at the macroeconomic level are to be found microeconomic level as well, but more detailed, allowing a more thorough analysis of the development of the tourist activity and also of the factors that influence it (Nicoleta Petcu, 2005). These indicators can be found as: absolute size, relative size of structure, coordination, strength, dynamic, average sizes and are arranged as follows (Cristache Silvia Elena et al 2005):

- indicators of tourism demand; indicators of tourism offer;

- indicators of supply-demand relationship

- indicators of results;

- indicators of the tourism economic efficiency indicators;

- indicators of the quality of tourist activity.

Indicators of tourism demand reflect the distribution and evolution of the external and internal global tourism demand in time.

The number of tourists is unanimously recognized as one of the most representative and important indicators of tourist traffic. It is a physical quantitative indicator and can be:

- arrivals / departures of tourists, for international tourism and it is obtained from the statistics recorded at the border;

- accommodated persons used both for the domestic and also for the international tourism, deduced from the statistics of means of accommodation;

- participants in the tourist activities - tourists and backpackers - proper to domestic tourism resulting from the centralization of business travel agencies.

The number of overnight stays or days- tourist, is calculated as the sum of products between the number of tourists and tourism activity duration in days. This information is obtained by processing data from the statistics of hotel units. 
The length of the stay represents the number of days spent by a tourist in a particular destination or a tourist accommodation and reflects the possibility of the offer to retain the tourist in an area, region. The length of stay depends on more factors: motivation of the movement, the income available for travelling, destination attractions, the services rendered.

The average duration of stay is calculated as the ratio of total days -tourist (NZT) and the number of tourists $(\mathrm{T})$ :

$$
\bar{D}_{s}=\frac{\sum N Z T}{T}
$$

Traffic tourist density connects the resident population of the receivers country (area, region) directly to the tourist traffic. This indicator is calculated as the ratio between the number of the arrived tourists in area $\mathrm{X}(\mathrm{T})$ and the resident population of the area $\mathrm{X}(\mathrm{P})$ :

$$
D=\frac{\sum T}{P}
$$

Usually this indicator has a subunitary value, but there are areas (Constanta county, where during the summer tourist season reaches the level of tourists traffic density 2.12) or countries (Spain, Austria) where the value is .

Relative prefference of tourists provides information on the geographical orientation of tourist flows originating from a pool of application (area, countru, etc); it s calculated as the ratio between the number of tourists from one county $\mathrm{Y}$ is heading to a country $\mathrm{X}\left(\mathrm{T}_{1}\right)$ and the resident population from the home country $\mathrm{Y}(\mathrm{P})$ :

$$
P_{y}=\frac{\sum T_{1}}{P}
$$

Another method of obtaining the relative preference of the tourists is commissioning in relation a number of tourists from an A country visiting a B country (ST1) and the total tourist emission of the country and also of country A (T). This method is less practical because not all countries follow the flow of tourists (tourist emission):

$$
F_{R}=\frac{\sum T_{1}}{\sum T}
$$

Seasonality represents a negative factor acting both on tourist satisfaction and the economic and financial results of operators in the tourism industry. Seasonal variation is one of the main characteristics of modern tourism.

Seasonality can be determined by means of several methods, namely: seasonbality indices, traffic intensity coefficients, coefficients of concentration. Seasonality indices, determined by simple or mobile arithmetic average method, based on the dynamic series of distribution, per months or quarters, of tourists' arrivals, confirms the concentration of tourism demand (Stănciulescu Gabriela Cristina Micu, 2009). Seasonality intensity, expressed as the degree of concentration, can be estimated using the Gini coefficient of concentration (CG) or corrected Gini (CGC).

$$
\mathrm{C}_{\mathrm{G}}=\sqrt{n \sum_{i=1}^{n} p_{i}^{2}}
$$




$$
\mathrm{C}_{\mathrm{GC}}=\sqrt{\frac{n \sum_{i=1}^{n} p_{i}^{2}-1}{n-1}}
$$

where: $\mathrm{p}_{\mathrm{i}}$ - unit weight to each element of the series, respectively $\sum p_{i}=1$;

$\mathrm{n}$ - number of times / elements of the series.

Tourism supply indicators are calculated for the supply of companies and reflects the distribution and variation in time and structure of their bid individually for each company making the offer. Tourism supply indicators can be grouped into assets indicators and labor indicators.

Indicators of employment in tourism allow us to consider the distribution of jobs in tourism sector according to the type of business, being aware of the time evolution of each one, assessing the specific difficulties of the tourism sector while activating the working needs in relation to the labour that is active or engaged in the national economy.

Indicators of supply and demand relationship inform about the activity of the dynamics of tourism operators. These indicators are very useful in practice as they reflect the degree of use of each tourism business, as well as the links between them.

Out of the indicators of results, the most important ones are the earnings and expendings indicators in tourism. The results of the most important category indicators are indicators in tourism receipts and expenditure. By combining these values with those physical indicators we determine other two indicators commonly used to characterize the tourist activity, namely: collection / average tourist expenditure and earning / expense-day average/ tourist for day-tourist.

The aggregate indicator of income is obtained by adding the revenue from transport, accommodation, meals, therapy, entertainment, extra services, sales of goods, currency exchange and others. International tourism expenditures represent the consumption expenditures for the purchase of goods and services of interest, made by residents of a country during a trip abroad.

The average revenuel expenditure per tourist are determined as the ratio between the amount of the value of revenue / expenditure and the number of tourists (arrivals / departures).

The average revenuel expenditure per tourist is determined as the ratio between the amount of the value of revenue / expenditure and the number of overnight stays (days-tourist).

Tourism's economic efficiency indicators are reflected in the database specific efficiency indicators specific to accommodation, catering, transport, leisure, business investment, international tourism.

Quality indicators of tourist activity stand for a set of specific components that contribute to the complete characterization of the tourist activity. They express the quality of the supply sides, the social, cultural and political effects of the tourist industry.

\section{Tourism and the main components of macro-environment in Romania}

Romania's international tourist traffic is characterized by a development that very closely reflects the changes, transformations at the political, economic and social level. A series of positive phenomena influence the dynamics and the structure of tourist traffic, such as globalization and internationalization of the social and economic life and the penetration of high technology into the sectors of the economy, industrializatio but also the negative phenomena are highly influential, on several aspects such as the global economic crisis, global warming, the expansion of poverty and unemployment.

Inbound tourism represents that part of tourism that records the arrivals of foreign citizens in a given country, citizens holding permanent residence in the issuing country (Oskar Snake, 2001). This form of tourism proves to be an important and effective source of foreign revenue for host countries. Between 2000-2009 the border tourist arrivals have fluctuated between 5.2 million in 2000, 4.7 million in 2002 and 8.9 million in 2008, accounting for loss in 2009. This trend should be 
related to the overall evolution of the political, economic, social environment Romania faced in that period.

Outbound tourism of Romania (represented by Romanian residents travelling abroad) is quantified in a broader framework through records at the border (departures of Romanian visitors abroad) and a specific framework with the help of tourist agencies that have organized trips abroad.

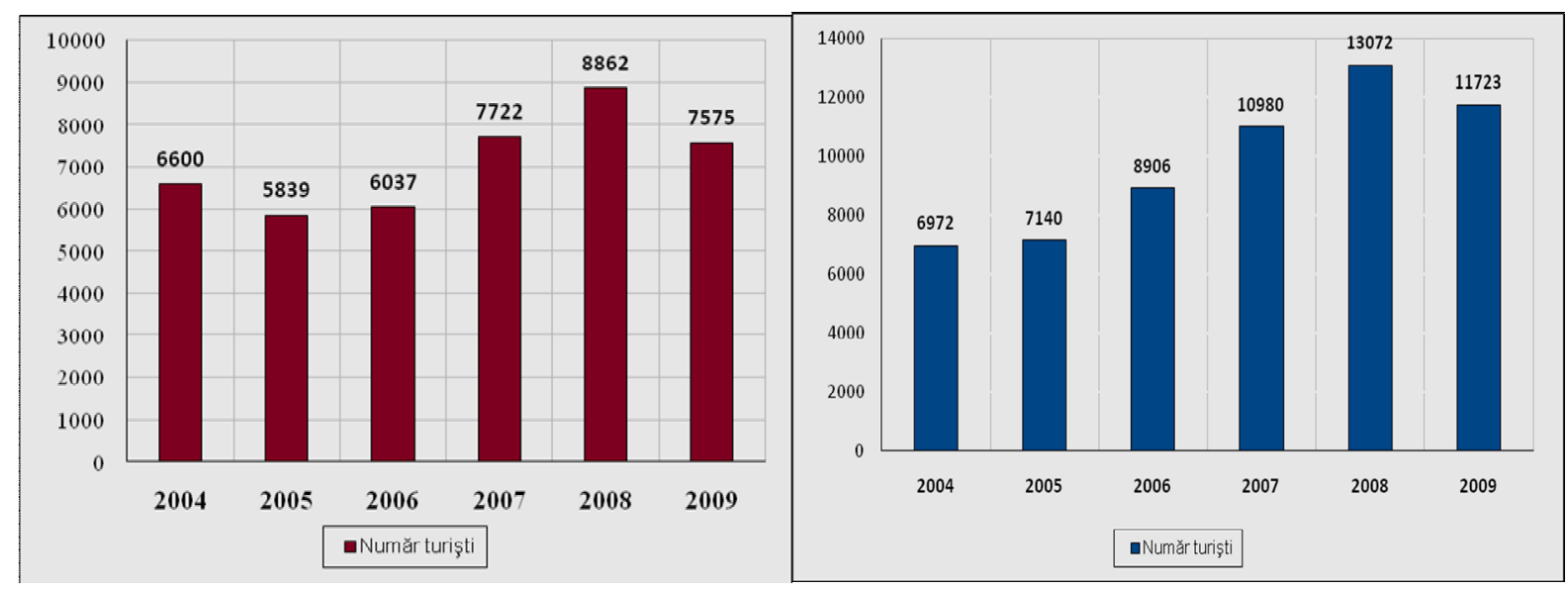

Figure no. 1. Evolution of tourist arrivals at frontiers and departures evolution of
Romanian tourists abroad in 2004-2009 (thousands) -

Source: Processed by the author according to Romanian Statistical Annuary 2010 -

Figure no. 1 illustrates the evolution of foreign tourist arrivals at the border and the evolution of Romanian tourists who leave abroad during 2004-2009. Noteworthy is the point of maximum reached in 2008 when there were 8.9 million tourist arrivals, representing an extra 2 million tourists compared to 2004. This was largely due to the increase of foreign tourist arrivals in neighboring countries such as Hungary. In 2009 the number of arrivals of foreign tourists in Romania falls by 1.3 million (15\%), mainly due to the global crisis. In the first 10 months of 2010 arrivals of foreign visitors reached a total of 6.4 million people and if we analyze the months of November and December of 2009 when their number was 1.1 million people, we might conclude that the arrivals in 2010 remain constant.

As far as the second flow is concerned, the departures of Romanian tourists abroad, note significant changes in 2004-2009.

The number of residents' departures abroad recorded a notable increase from 6972 thousand in 2004 to 13,072 thousand in 2008, an increase of almost 50\%. The explanation for this development lies in the explosive opening of international politics of Romania, in the facilities granted by the Romanian government to potential and in the responsiveness of European countries to the desires of the population. This particular increase in departures of tourists has turned Romania from a receiving country into an emitting country. However we express in favor of a more careful analysis of the factors that increase the number of departures for foreign tourist destinations. In Romania, due to a policy that was wrong regarding the price quality ratio in the hospitality industry, the effects of this policy are currently manifested by massive customer orientation towards foreign tourism markets.

Departures of Romanian tourists abroad in 2008 increased by $19 \%$ and $23 \%$ in 2007, thanks to the fact that Romania joined the European Union and border formalities are more simplified. In 2009 we note a decrease in the number of departures of residents towards destinations outside Romania with 1.3 million (11\%), having the global economic crisis as the determining factor. 
As far as means of transport used in 2009 are concerned, both in terms of arrivals and departures, in Figure 2 we mainly notice the use of road transport means, then air and rail vehicles, the lowest share being hold by naval means $2 \%$.

Globally compared, the largest share in what means of transport are concerned, is hold by the air transport, the road transport holding the second place, last place being occupied by rail transport.

For the future a significant increase in the use of plane as means of transport for Romania is expected, due to the increased number of low-cost airlines, which will become increasingly accessible to a large mass of passengers.
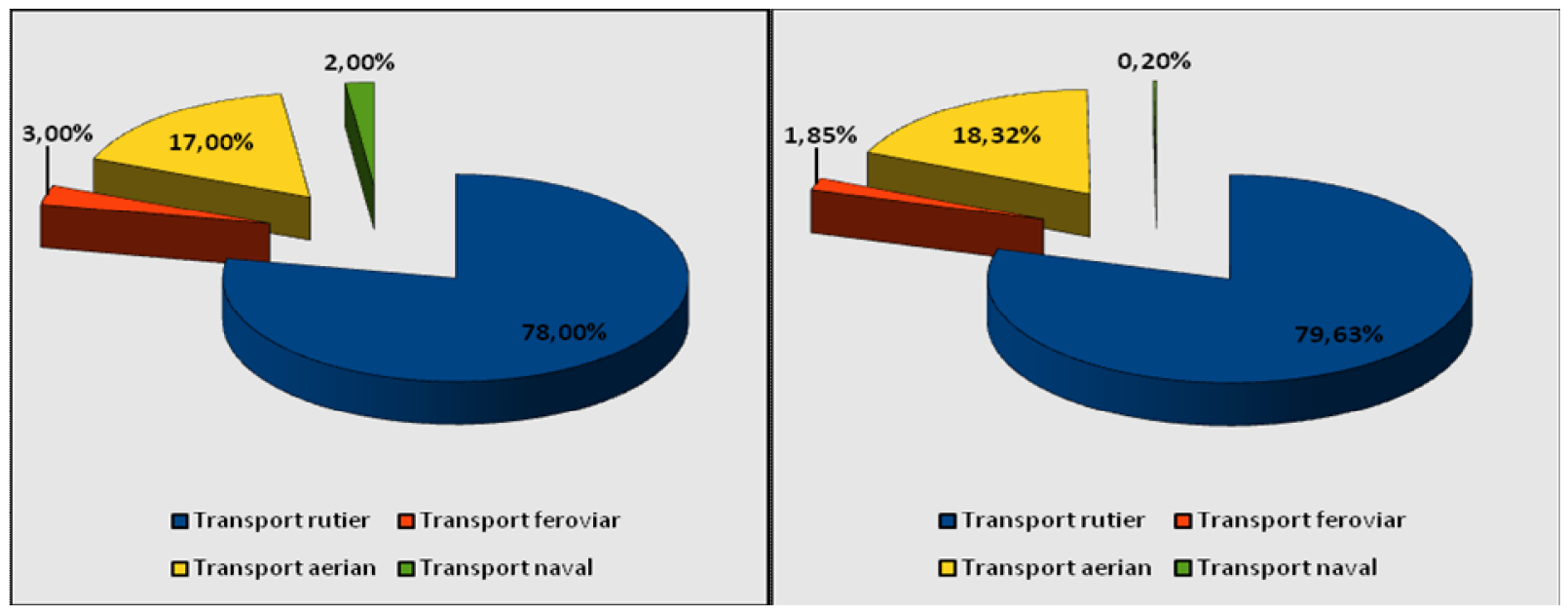

\section{Figure no.2. The share of tourists arrivals and departures, depending on the means of transport used in 2009}

Source: Processed by the author according to Romanian Statistical Annuary 2010

In terms of spatial distribution, the receptor tourist flow has seen a strong focus. Most of the tourists who visited Romania in 2004-2009 were Europeans, about 95\%, or 6.306 million out of a total of 6.600 thousand in 2004 and 7.203 million out of a total of 7.575 million in 2009. At a distance, the second position was hold by Asia, which recorded 171,000 tourist arrivals in Romania in 2008, America coming after it holding the third place with 169 thousand tourists, maintaining the same position as in 2007 (in period 2004-2006 was ranked secondly) while Australia and Oceania are placed last in the hierarchy.

In the field of international tourism in 2008, the number of foreign visitors in Romania increased with $14.0 \%$ as compared to the previous year. There were 8.862 billion visits from outside our country, mostly from Europe. It was mainly the case of people who visited due to ties of kinship or friendship with people of our country. In this case, most visits were made from Germany, the United States, Israel, France, Moldova and other countries where there is a significant number of people of Romanian origin (Constantin Anghelache, 2008). If 2008 was the peak in the number of tourist arrivals, in 2009 the effects of the worldwide economic crisis were felt, and the number of tourists decreased by $15 \%$ over the previous year. In the last two months of 2009 the number of tourist arrivals was of 1,055,000 people. If the levels remain steady in November and December 2010 the number of tourists throughout the year 2010 would be 7.488 million people, that is approximately equal to that of the year 2009. Seasonality, ie the activity concentration at certain times of the year is one of the important features of the Romanian tourism.

In 2004, out of the total number of foreign tourists arriving in Romania, 58\% came from European Union countries. In 2006, the share drops to 46\%, whereas in 2007, the year of integration 
into the European Union to increase up to $62 \%$ threshold at which remains in 2008 as well, whereas in 2009 there is a slight increase to $63 \%$.

It is also the case of overseas departures, where there is the same very tight concentration when it comes to travelling destinations. According to the latest data provided by the National Institute of Statistics, Romania's outbound tourism is geared almost entirely to countries of Europe. Out of the European countries, in 2007, it was Italy that hold the dominant position with $22 \%$ of all trips made abroad by the Romanian visitors. In 2007, the European destinations preferred by Romanian residents were Greece, Hungary, Spain, Germany, Bulgaria, Austria and France.

According to data presented by the National Institute of Statistics in 2009 only $38 \%$ of the number of Romanian tourists that went abroad aimed recreation and leisure, the largest share, in terms of motivation, being visiting relatives and friends. As far as destinations are concerned, the pilgrimage and treatment departures are at a significant distance (4.1\%), while departures meant for business and other professional reasons hold the last position.

Regarding the tourist arrivals in the establishments of tourists' accommodation functioning as accommodation places, the situation is as follows:

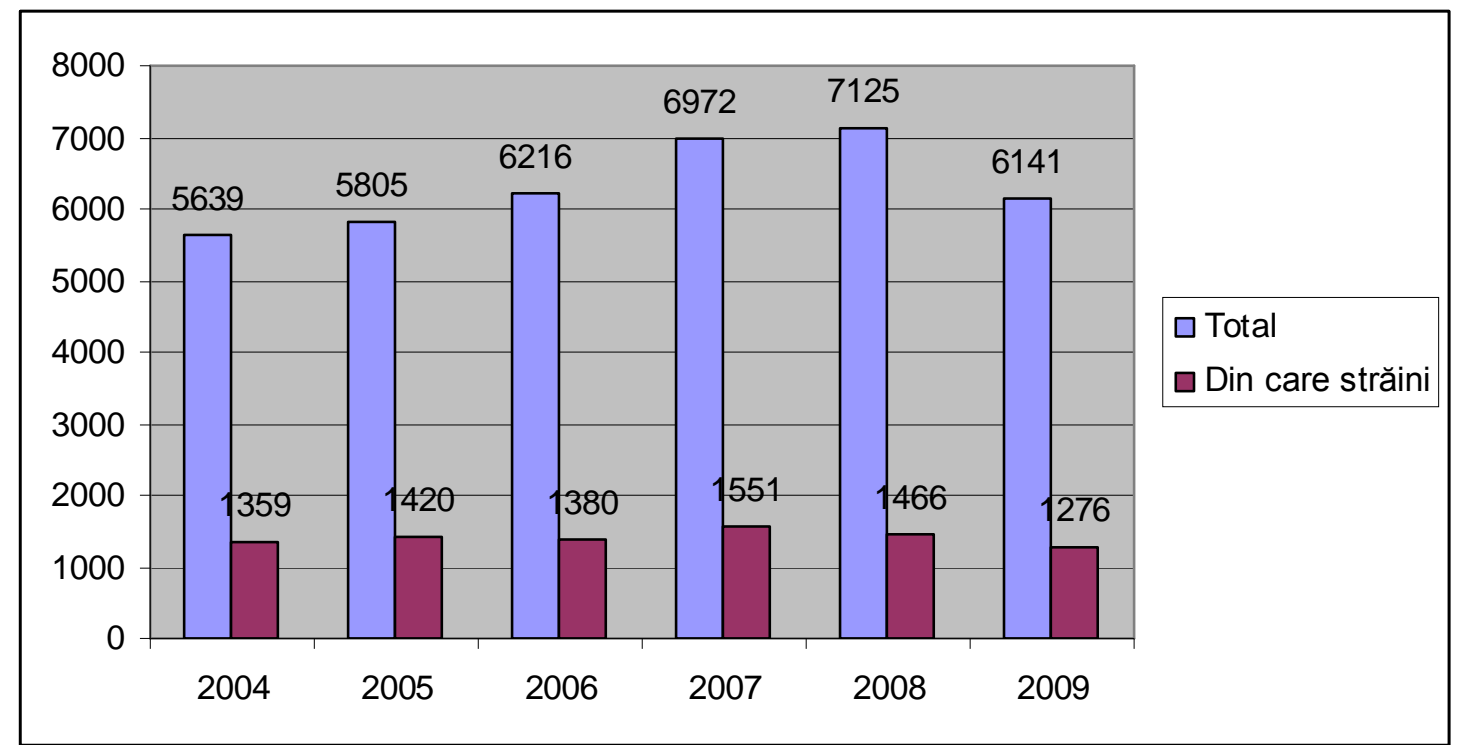

Figure no 3. The evolution of tourist arrivals in tourist receptions in 2004-2009 (thousands)

Source: Statistical Annuary of Romania 2010

If in 2004 the share of foreign tourists in the tourist reception with functions of accommodation was 24\%, it drops slightly in 2007 representing 22\%, while in 2008 and 2009 it is maintained at $20 \%$. This situation must constitute a warning to the management of this activity domain.

In Romania, most of the trips taken by residents are short (1-3 nights), representing $51 \%$ in 2008 and 59\% in 2009, and as far as the predominant destination is concerned, for short trips is concerned, the choice is for the mountainous areas and for religious tourism and visiting worship places. The year 2009 also notes the strong growth of tourist preferences for the Danube Delta, a unique area in Europe, the growth being of almost 5 times. As for the other destinations (seaside, mountain, resort spas, tours) an increase is also noticeable, sti One way to increase the number of tourists in Romania would be to increase investment in this sector that is seen as the national economic engine in other countries. This requires investment in infrastructure, capacity of accommodation in restoration establishments, protecting natural and human resources, investment in new attractions, why not investment in the animation and support activities for the hospitality industry that are not to be neglected. Lastly, but not least, investments in the workforce should be 
considered, as well as the high qualification of employees in this sector and becoming aware of their importance and the particular role they have to increase the index of competitiveness in the hospitality industry.

Data provided by the National Institute of Statistics on investment in hotels and restaurants are to be found in the following table: 
Table no. 1

The development of investments in hotels and restaurants during 2005-2009 (mn)

\begin{tabular}{|l|l|l|l|l|l|}
\hline \multicolumn{1}{|c|}{ Year } & \multicolumn{1}{c|}{2005} & \multicolumn{1}{c|}{2006} & \multicolumn{1}{c|}{2007} & \multicolumn{1}{c|}{2008} & \multicolumn{1}{c|}{2009} \\
\hline Total investment (out of which) & 47.851 & 68.827 & $83.660,6$ & $99.525,6$ & $74.939,3$ \\
\hline Investment in hotels and restaurants & 936,6 & $1.249,9$ & $1.600,9$ & 1993 & $1.353,3$ \\
\hline
\end{tabular}

Source: Processed by the author according to Romanian Statistical Annuary

There is a steady increase in value of investments in hotels and restasurante by 2008 , but their share in total investment in the economy affiliation varies between $1.81 \%$ in 2006 and $2 \%$ in 2008. In 2009 investments fall in value by 639.7 million lei as well as a share of $0.2 \%$ compared to 2008.

According to data provided by the NBR direct investment position in hotels and restaurants are as follows: in 2006 there has been a significant increase in foreign investment in the capacity of accommodation and restaurants in the hospitality industry from 42 million in $2005(0.2 \%$ of of 21.855 million euros) to 283 million euros ( $0.8 \%$ of the total 34.512 million euros). Note that in 2006 the amount of Greenfield investments in hotels and restaurants is 205 million euros. In 2007, direct investment share of total direct investment in Romania is $0.6 \%$ for 2008 and 2009 and then decline to $0.4 \%$.

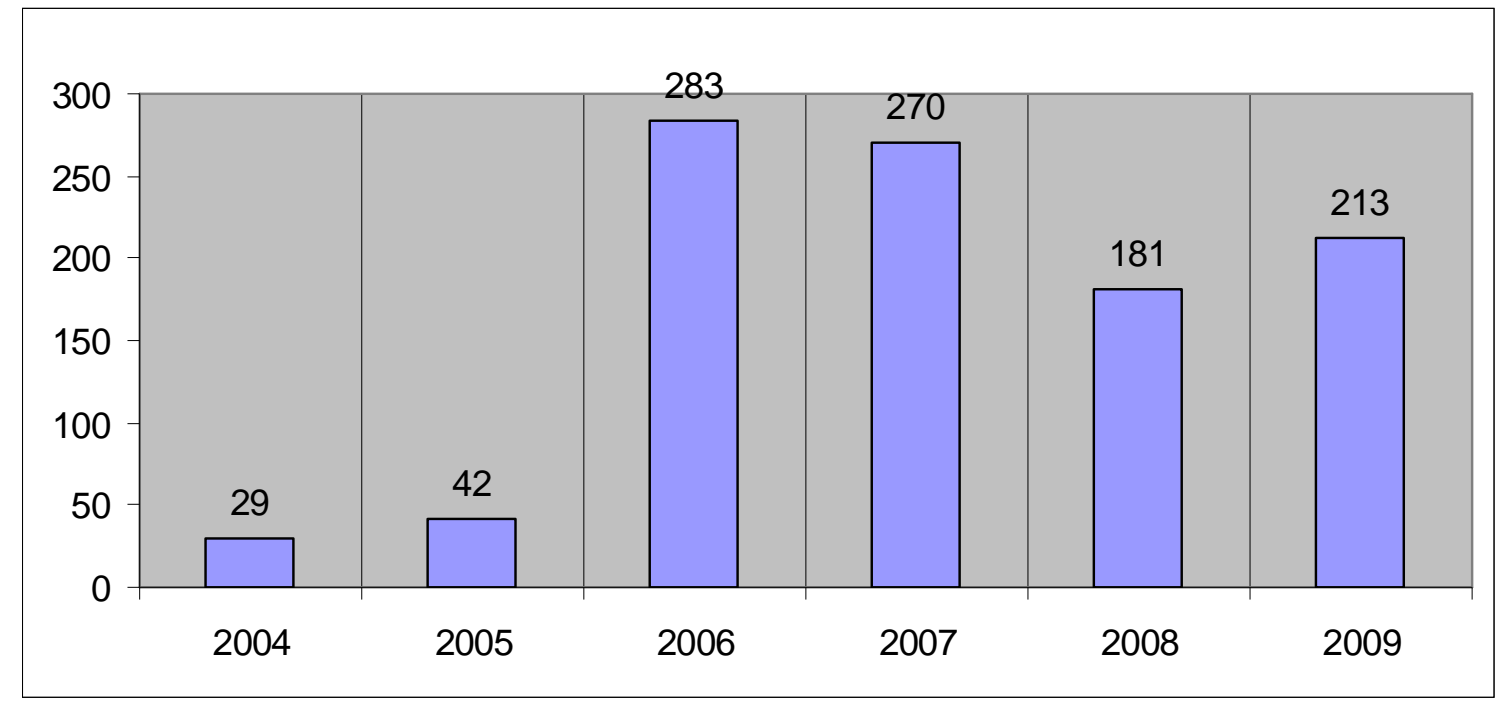

Figure no. 4 Foreign Direct Investment in hotels and restaurants in 2004-2009 (million euros)

Source: Processed by the author according to the NBR statistics www.bnr.ro, accessed 01/22/2011

The small share of investments in the hospitality industry is also reflected in the small number of tourists reception units with functions of accommodation. Between 2008 and 2009 the number of tourist reception units with functions of accommodation classified by the degree of comfort they offer are presented in Table 2.

Table no. 2 .

Number of structures with functions of tourist accommodation according to the category of comfort

\begin{tabular}{|l|l|l|l|l|l|l|l|}
\hline Year & Total & 5 stars & 4 stars & 3 stars & 2 stars & 1 star & Unclassified \\
\hline 2008 & 4,840 & 65 & 291 & 1,165 & 2,151 & 888 & 280 \\
\hline 2009 & 5,095 & 69 & 367 & 1,487 & 2,072 & 850 & 250 \\
\hline
\end{tabular}

Source: The Statistical Annuary of Romania 2010

Data provided by the National Institute of Statistics show in the first place, the increase in the structures having accommodation capacity from 4840 in 2008 to 5095 in 2009, but also the the 
increase of investment in all that means comfort in an accommodation unit, so that in 2009 many accommodation establishments have been reclassified. Nevertheless the share of the structures classified inferior categories of two-star comfort and a star comfort is high, being $44 \%$ in 2008, $40 \%$ in 2009 for two-star establishments and $18 \%$ in 2008, 16.6\% in 2009. Also unclassified units have a higher percentage (6\% in 2008) even though in 2009 there was a decrease in number and their share out of the total number of tourists reception units with functions of accommodation.

Major changes in the global economy, resulting in significant increases in the production of each country, but also in the decrease of political and trade barriers between countries, led, after 1970, an explosive trend in the number of travels and of countries taking part in countries tourist traffic, enhancing communication in this area and increasing the need for tourist information.

There are few developing countries where the share of tourism contribution to GDP is around 10\% (China, India, United Arab Emirates), or even more (Venezuela 18\%). We can state that in these countries tourism has an important contribution to the national economic growth. Unlike those in Romania, the hospitality and tourism industry's contribution to GDP is very low ranging from $0.9 \%$ in 2000 and $1.87 \%$ in 2007.

The impact of tourism in GDP in 2004-2009 (millin lei)

\begin{tabular}{|l|l|l|l|l|l|l|}
\hline Year & 2004 & 2005 & 2006 & 2007 & 2008 & 2009 \\
\hline Total GDP & $247.368,0$ & $288.954,6$ & $344.650,6$ & $416.006,8$ & $524.700,0$ & 498007,5 \\
\hline $\begin{array}{l}\text { Hotels and } \\
\text { restaurants }\end{array}$ & $3.803,6$ & $5.089,9$ & $6.621,5$ & $7.817,3$ & $8.727,3$ & $8.534,8$ \\
\hline $\begin{array}{l}\text { Impact } \\
\text { expressed } \\
\text { in \% }\end{array}$ & 1,53 & 1,76 & 1,92 & 1,87 & 1,66 & 1,71 \\
\hline
\end{tabular}

Source: Statistical Annuary of Romania 2010

Freedoms of Tourism Development Master Plan for the Period 2007-2026 forecasts an increase of the hospitality and tourism industry's impact on the national economy estimating a growth of the contribution of this sector to GDP of 4,3\% in 2011, 4,9\% in 2016, 5, 9\% in 2021 and $6,9 \%$ in 2026 . But all estimates made before the crisis might be null as they are too optimistic..

Tourism, because it is a labor-intensive living, plays an important role in the distribution of labor. It creates new jobs, thus helping to attract surplus labor from other sectors, which has as direct effect of reducing unemployment. Remaining in the labor area, we should consider the indirect effect of increasing the number of people employed in this sector. Studies show that direct employment in tourism may create 1 to 3 indirect and induced jobs. This is explained by the fact that the hospitality and tourism industry, being a major consumer of goods and services positively affects labor use in agriculture, food industry, construction industry suppliers considered.

According to data from the National Institute of Statistics in 2008, the number of persons employed in hotels and restaurants is 154,000 , whereas in 2009 the number of people employed in this sector is 165,000 . Thus, an increase of $7 \%$ is to be noted. One negative impact on employment in this sector is the seasonality. If in December of 2010, 103,800 people were reported as employed in hotels and restaurants, in July the number of employed people was 114,800 . As you can see most employees are in the age group 25-34 years, ie 53295 persons and the age group 35-44 years, ie 48 860 persons. This situation could be a strong point for this area in the sense that young people are open to innovation, to a different perception of the importance of this sector for the national economy by changing their attitude. Regarding the structure of labor by sex, most employees in this sector are women, their share out of the total personnel being $63.8 \%$ ie 105270 persons. 
The analysis of the outbound tourism indicators requires the knowledge of the expenditure of Romanian tourists abroad.

Table no. 4

The balance of payments of international tourism of Romania in 2004-2009 (million euros)

\begin{tabular}{|c|c|c|c|c|c|c|}
\hline Year & 2004 & 2005 & 2006 & 2007 & 2008 & 2009 \\
\hline Collections & 406 & 852 & 1,034 & 1,171 & 1,358 & 884 \\
\hline Payments & 434 & 750 & 1,035 & 1,119 & 1,477 & 1,051 \\
\hline Balance & -28 & 102 & -1 & 52 & -119 & -177 \\
\hline
\end{tabular}

Source: Processed by the author according to the information presented by the National Bank of Romania, www.bnr.ro.

The growth of the Romanian tourist expenditure abroad was mainly associated with the increased number of departures. Analyzing the balance of payments balance of international tourism of Romania, we noted that since 2004 it has been negative, observation based on the increased number of Romanian tourists who went abroad (unfortunately too little due to the rise in the number of foreign tourists who arrived in Romania). In 2009 tourism and travel position in the balance of payments registered an increase of 167 million euros, up by $40.3 \%$ compared to 2008, due to the sharp reduction in business travel revenue. If business travel revenue in 2008 was 1.077 million euros and 643 million euros in 2009, payments were 752 million in 2008 and 666 million in 2009. The National Bank of Romania presents data about private tourism as well, as in 2008 it generated a deficit of 444 million euros, and in 2009 it fell to 144 million euros. A full picture of the size, trend and structure of domestic and international tourist traffic requires, on one hand, mobilizing a greater number of indicators and, on the other hand, deepening the causes / reasons behind them.

\section{Conclusions}

The overall analysis of Romania's international tourist traffic shows its modest level compared to the resources of our country and thus increases reserves in the future. International tourism development and better capitalization of the natural and human potential, imply on one hand, efforts to relaunch the Romanian economy, on which tourism heavily dependents and, on the other hand, conceiving an appropriate strategy, with its main objective as: offering high quality services, modernizing the specific materials and general infrastructure, performing an aggressive promotional policy, broadening international cooperation in the field.

The objectives of decision makers in the hospitality and tourism industry are transforming Romania into a quality tourist destination based on its natural and cultural heritage to meet European Union standards regarding the provision of goods and, services by 2013 and achieve a sustainable development from the environmental and tourist point of view with a growth rate superior to other destinations in Europe.

Arrivals are expected to grow by 2.5 times between 2006-2026, representing an average annual growth of $4.8 \%$, meaning more than double as compared to the World Tourism Organisation estimates on visitor entries within the Vision for Europe by 2020. The growth will be faster for European Union countries (5.5\% per year) and countries outside Europe ( $8 \%$ per year) than for countries outside the European Union (3.1\% per year). Data include all arrivals, including tourists and holiday visitors daily. (Master Plan for National Tourism Development 2007-2026, page 167). We could say that these forecasts are too optimistic because at the time of their formulation does not provide for the emergence of a global financial crisis whose effects will strongly affect the hospitality and tourism in Romania without a proper strategy to be implemented with determination. 
To reach these targets in point of the increase of the number, which will impact on GDP growth we recognize that concerted efforts are needed to increase investment in this sector, so investment in improving the quality of material and infrastructure in Romania.

A great emphasis should be set on improving staff attitudes, a change that requires the development and implementation of a general program of increased awareness of the hospitality and tourism sector in terms of responsibility towards their work and care to the customer. Structural problems that have to do with the crisis of qualified staff, poor quality and low quality of service attitude and service to customers in the hospitality industry in Romania, can be resolved only through a human resources development strategy clear and firm for the entire sector the hospitality and tourism. Should be given A high priority should be granted to the training of the existing staff in hotels, hostels, restaurants, and the animation industry by supporting activities on practical skills, skills for serving food and drinks, preparing and cooking food for the holiday party organization , recreation, treatment included in the packages. It is not hard to ignore The issue of promoting Romania as a tourist destination is not to be neglected, by promoting the natural and man-made attractions in some cases unique in Europe. The most important promotion can be done by increasing the quality of services and products offered by hospitality and tourism industry by changing the Romanian citizens' attitudes towards tourists, but mostly by changing the attitude of this sector bidders.

We are sincerely in favor of cultivating a mentality that looks at tourists etymological meaning of the word hospitality (host or person who receives guests giving them protection and comfort). From contemporary hospitality is rarely a metter of protection and survival, and is more associated whit the label and entertainment. However, it still requires respect for guests, offering everything necessary for their needs and treating them as equals.

\section{References}

1. Anghelache C. 2008, România 2008, Starea economică în procesul integrării, Editura Economică, Bucureşti.

2. Cristache S. E., Bădiţa M., Iacob A. I., 2005, Statistică aplicată în managementul turistic, Editura ASE, Bucureşti.

3. Cristureanu C., Strategii si tranzacții în turismul internațional, 2006 Editura C.H. Beck, Bucureşti.

4. Franklin A., 2003, Tourism An Introduction, Sage Publications Ltd.,

5. Hapenciuc C. V., 2004, Elemente de analiză şi prognoză în turism, Editura Junimea, Iaşi.

6. Minciu R., 2004, Economia turismului, Editura Uranus, Bucureşti.

7. Nistoreanu P., 2005, Economia turismului - teorie şi practică, Editura ASE, Bucureşti.

8. Petcu N., 2005, Statistica în turism 2005. Teorie şi aplicaţii, Editura Blue.

9. S Medlik, 2003, Dictionary of Travel, Tourism and Hospitality, Butterworth Heinemann.

10. Smith Valene L and Eadington W., 2002, Tourism alternatives Potential and Problems in the development of tourism, International Academy for the Study of Tourism.

11. Snak O., Baron P., Neacşu N., 2001, Economia Turismului, Editura Expert, Bucureşti.

12. Stănciulescu G., Micu C., 2009, Economie şi gestiune în turism.Probleme, proiecte şi studii de caz, Editura C.H. Beck, Bucureşti.

13. Stănciulescu G., Lupu N., Țigu G., 1998, Dicționar poliglot explicativ de termeni utilizați în turism, Editura ALL, Bucureşti;

14. *** Master Planul pentru dezvoltarea turismului național 2007-2026

15. *** Anuarul statistic al României pe anul 2009, 2010

16. www.bnr.ro.

17. www.wttc.org/

18. www.insse.ro/ 